Submitted $8^{\text {th }}$ May 2021

Accepted $30^{\text {th }}$ June 2021

\title{
INVESTIGATING THE IMPACT OF SENSORY EXPERIENCE ON BUDGET HOTEL ROOMS TO MAXIMIZE GUESTS SATISFACTION
}

\author{
Reiza Miftah Wirakusuma ${ }^{1}$, Anak Agung Anom Samudra ${ }^{2}$, Ni Kadek Sumartini ${ }^{3}$ \\ Universitas Pendidikan Indonesia, Indonesia ${ }^{1}$, \\ Institut Pariwisata dan Bisnis Internasional, Indonesia ${ }^{2,3}$ \\ reizamiftah@upi.edu
}

\begin{abstract}
This study aims to investigate the sensory experience from guests who have stayed at a budget hotel in Bandung, West Java Province. Although only offers low prices, simple facilities, and less spacious room, yet a budget hotel has been able to maximize comfort and satisfaction for their guests. Subsequently, the number of budget hotels increase significantly in the past few decades and create different themes for hospitality industry. These themes create unique experience and they are felt by five senses of guests during their visits. The experience is divided into visual, tactile, gustatory, auditory, and olfactory. The method used in this research is a qualitative descriptive analysis from 145 questionnaires which were collected on the field. The results showed that the sensory experience had a dominant impact on guest satisfaction in staying at a budget hotel, especially in tactile and visual.
\end{abstract}

Keywords: Sensory Experience; Guests Satisfaction; Budget Hotel

\section{INTRODUCTION}

Within decades, the development of tourism and hospitality industry in Bandung, West Java Province is rising significantly, as a result, economic growth is much influenced number of hotels, both classified and non classified to cater the rising of domestic tourists. The city of Bandung has been known as a tourist city since the Dutch colonial era (Nurwulandari \& Kurniawan, 2020) and currently the development of Bandung tourism is very rapid. Many factors influence such as ease of access between Bandung and Jakarta as the capital of the country, in parallel of the development of infrastructure, and the emergence of low-cost airlines.

According to data from Jawa Barat Province in Figures in 2020, it can be seen at table 1 . The number of hotels in the city of Bandung was accounted for 336 units with various hotel classifications. The data shows that the tourism industry is developing well. It is because accommodation is one of the important sectors of tourism. This figure also shows the increasingly fierce competition in the hotel business in Bandung. 
Table 1. Number of Accommodations, Available Rooms and Beds in Classified and Non Classified Hotel in Bandung Municipality, 2012-2019

\begin{tabular}{|c|c|c|c|c|c|c|c|c|}
\hline & 2012 & 2013 & 2014 & 2015 & 2016 & 2017 & 2018 & 2019 \\
\hline \multicolumn{9}{|c|}{ Classified Hotel } \\
\hline $\begin{array}{l}\text { Total of } \\
\text { Accommo- } \\
\text { dation }\end{array}$ & 93 & 99 & 109 & 124 & 147 & - & 180 & 195 \\
\hline $\begin{array}{l}\text { Total } \\
\text { Rooms }\end{array}$ & 9.254 & 9.882 & 10.913 & 12.712 & 14.726 & - & 14.996 & 19.060 \\
\hline
\end{tabular}

\begin{tabular}{|c|c|c|c|c|c|c|c|c|}
\hline \\
\hline \multicolumn{9}{|c|}{ Total of } \\
\hline $\begin{array}{l}\text { Accommo- } \\
\text { dation }\end{array}$ & 208 & 229 & 231 & 240 & 238 & - & 239 & 227 \\
\hline Total & 5.131 & 5488 & 5828 & 6532 & 6486 & - & 7027 & 5720 \\
\hline
\end{tabular}

Source: Jawa Barat Province in Figures, 2020

Responding to the increasing demand for tourists also affects the growth of budget hotels. Budget hotels come as cheap accommodation options for tourists. Budget hotels have grown a lot in the city of Bandung, accompanied by the needs of tourists who want cheap accommodation. The features that are generally accepted from budget hotels are limited services, simple rooms, standard accommodation, low cost, low construction and operating costs, and less than 150 rooms (Mohsin \& Lengler, 2015). In this research, we follow the definition (Xuejing \& Huamin, 2009) that budget hotels provide simple and comfortable accommodation at low prices. Budget hotels are arguably hotels with minimal facilities but that does not mean there are no such facilities, tourists can request or can also choose packages facilities that could be provided by the hotel management. This is because the prices offered by hotels are very minimal below the prices of other conventional hotels. Even buildings or hotel buildings tend not to be too expensive in investment, some parts do not use heavy materials or materials such as rooms insulated with lightweight materials such as gypsum or GRC and even plywood. But by not reducing the beauty of the hotel. Budget hotels are also identical to budget hotels, hotels that are affordable and fit the needs of someone who only needs a bed without other facilities.

Kotler (2000) states that "Satisfaction is a feeling of pleasure or disappointment someone who appears after comparing the performance (results) of the product thought to the expected performance". According to (Aryani, Dwi, 2011), Consumer satisfaction is a situation that is shown by consumers when they realize that their needs and desires are as expected and well fulfilled. Meanwhile, according to Bakhtiar et al, (2010), consumer satisfaction is a positive feeling of consumers associated with service products during use or after using services or products.

Customer satisfaction and dissatisfaction with the product or service will affect the next pattern of behavior. If the consumer is satisfied, then he will show the magnitude of the possibility to return to buy products or enjoy the same service. Based on the above meanings, it can be concluded that customer satisfaction is an 
emotional assessment of the use of a product or service where the expectations and needs of consumers are met each other.

In the development of the tourism industry, hotels are needed by tourists as lodging services to rest in a tourist destination. Of the various hotels located in a tourist destination, each hotel has a different rating from the tourists who visit, the tourists can judge it from the Sensory Experience that has been felt by visitors at each hotel. Sensory experience is an attempt to create experiences related to human sensory. This is not only related to human sensory, but the atmosphere and can affect human psychology. In sensory experience, the five aspects of human sensory become the main target in the visiting experience. In addition to the services provided by tourists, they also feel the comfort of their body sensors.

Wickens (2004) found that $83 \%$ of humans use visuals to receive messages. Therefore, businesses will focus on the general feeling of this performance, and invest considerable resources. The human visual sense is the most advanced and prominent is the intellect (Sachari, 2007). Of the five human senses, the sense of sight is then also the meaning that has been focused on mostly by salesmen (Agapito, 2020). Therefore, color can have an important role in the success of marketing stimuli, such as the colors used in advertisements or the colors used for package design (Mylonas \& MacDonald, 2017). The sense of smell is the most direct, and smell can significantly affect one's evaluation and other people (Wulandari, 2014).

Sensory experience or experience by using various senses such as seeing, feeling, hearing, smelling, and touching, contributes to form a unique relationship between the perceptions of tourists and their goals (Agapito et al., 2012). Tourism forms a unique bond between tourists and tourism products through sensory experience. Connecting the human senses of seeing (visual), kissing (smell), hearing (hearing), tasting (gustatory), and touching (tactile) (Budhi Danudara, 2016). Thus, the sensory is closely related to the experience of tourists in traveling. Also, sensory experience, customer satisfaction, and loyalty are related to a high level of cause and effect relationships. This effort was made to explore the relationship between sensory experience, customer satisfaction and customer loyalty for customers (Guzel, 2016).

Kotler (2000) introducing the term "atmosphere" the impact of environmental sensory stimuli, such as sight, sound, smell, and touch, on the intention of consumer behavior. Besides, little research has been carried out to determine the importance of sensory aspects and the role of multisensory in the world tourism experience, even though it has attracted the interest of tourism geographers (Rahman et al., 2015).

Sensory experience relates to the nature of observation, which promotes awareness of one or more of the five senses, through observation, using your senses to understand the world around you: visual, taste, smell, touch, hearing (Guzel \& Dortyol 2016). Moreover, color can have an important role in the success of marketing stimuli, such as the colors used in advertisements or the colors used for package design (Mylonas \& MacDonald, 2017). Not only vision or eyes but the sense of smell is the most direct, and smell can significantly influence a person's evaluation of things and others (Hudspeth \& Logothetis, 2000). Therefore, the sensory experience can be defined as an important aspect in the experience of tourists or visitors.

Previous studies of sensory experience in Airbnb resulted that social interaction between guests and host is essential because it generates positive 
reviews (Sthapit \& Jiménez-Barreto, 2018). Other research pointed out that experiential marketing was crucial from affective, affective, sensory attributes to choose desired hotel (Kim \& Perdue, 2013). Another recent bibliometric studies stated that there was a connection between tourism experience and places attachment (Kastenholz et al., 2020), furthermore the research indicated that in the future the topic will be related to sustainability and technology (Agapito, 2020). Sensory spatial experiences are also proven to have connectivity with positive direct and indirect impacts on behavioral intention (Dai \& Zheng, 2021). Nowadays, these behaviors either positive or negative are reflected on online review and rating from marketplace and online travel agent (Mehraliyev et al., 2020). Nearly similar research has been conducted on Resort sensory experience based on online review which has result in point out the sight experience was the utmost important (Rahman et al., 2021).

However, studies on guests' hotel sensory experience topics are still very limited, predominantly on budget hotel. Therefore, this study can be considered as a positive contribution to the topic. For this particular reason, this study aims to investigate guests' sensory experience during their visits to budget hotel in Bandung.

\section{METHODOLOGY}

This study, proposed to analyze and reveal the effect of sensory experience on budget hotel guest satisfaction. In gathering, revealing various problems of the objectives that were made, this research was conducted with an analytical descriptive study approach. According to (Sugiyono, 2010) that descriptive qualitative research is a research method based on the philosophy of post positivism, which is usually used to examine natural objective conditions where the researcher acts as a key instrument. Meanwhile (Bogdan \& Biklen, S. (1992), 2009) defines the descriptive method as a method that describes an objective situation or event based on facts that appear or should be followed by an attempt to draw general conclusions based on historical facts.

The research methods that is included in determining the location of budget hotels in Bandung, especially in national or local chain hotel. The sample hotels are Posters Hotel, Concordia, Amaris, Zodiak Hotel, Vio Hotel, Ibis Budget, and Favehotel. Next, the questionnaires were distributed in a google form to tourists who had stayed at a budget hotel. The questionnaire contains questions that are useful for analyzing indicators that affect the sensory experience of guests in staying at a budget hotel. The data we obtained were then analyzed using descriptive analysis methods. 


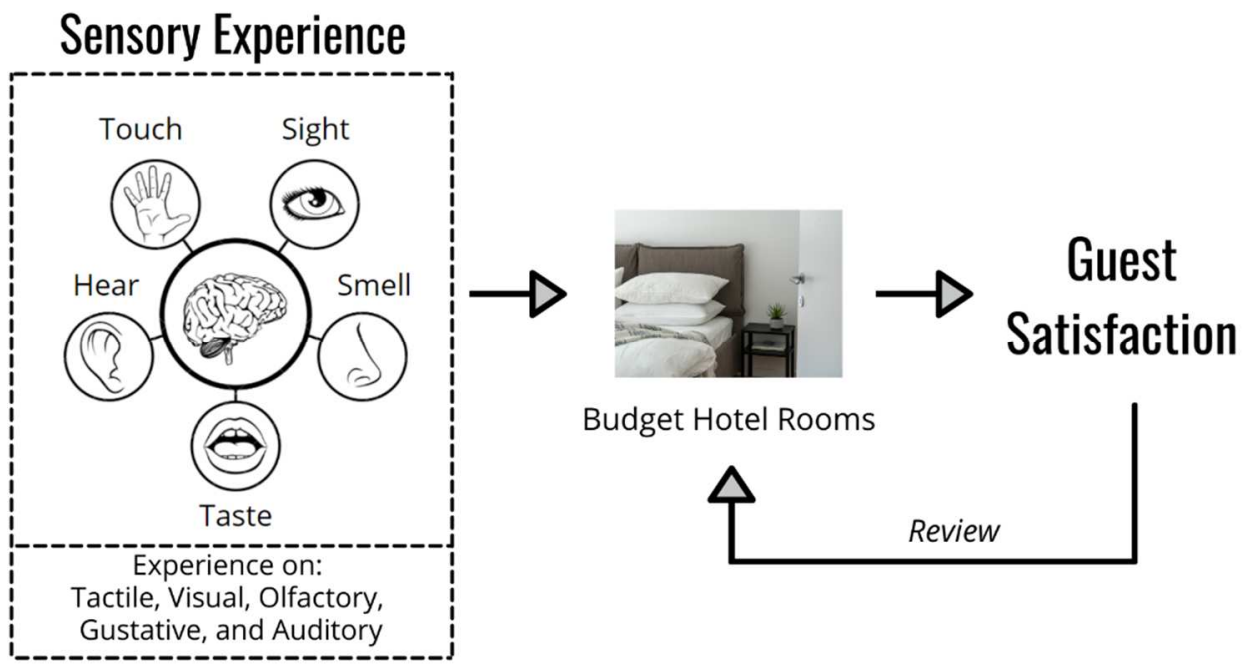

Fig.1 Conceptual Framework

Conceptual Framework in this study as can be seen on Figure 1, points out unique experience that felt by five senses of guests during their visits. The experience is divided into visual, tactile, gustatory, auditory, and olfactory towards their activity at budget hotel. Afterwards, the guests were asked whether they have reached comfort and satisfaction or they only get disappointment. Finally, the guests were asked if they put positive or negative review for the hotel.

\section{RESULTS AND DISCUSSION}

As can be seen on table 2, the profile of 145 respondents are divided into gender, age, education level, area of origin, travel companion and visiting frequency to budget hotel in Bandung. Female respondances were $61 \%$ and majority were between 18 to 40 of age group. Most respondents were graduated from university and reside from area of Jakarta. They visited the budget hotel with their family with frequency of first timer.

Table 2. Profile of Respondents $(\mathrm{N}=145)$

\begin{tabular}{llc}
\hline \multicolumn{1}{c}{ Category } & \multicolumn{1}{c}{ Indicator } & $\mathbf{\%}$ \\
\hline Gender & Male & $39 \%$ \\
Age & Female & $61 \%$ \\
& $18-23$ & $23 \%$ \\
& $24-30$ & $29 \%$ \\
& $31-40$ & $37 \%$ \\
Education Level & $41-50$ & $5 \%$ \\
& $51-60$ & $5 \%$ \\
\multirow{3}{*}{ Area of origin } & Above 60 & $1 \%$ \\
& Highschool & $21 \%$ \\
& Graduate & $65 \%$ \\
& Postgraduate & $14 \%$ \\
& Jakarta & $32 \%$ \\
& Tangerang & $27 \%$ \\
\hline
\end{tabular}




\begin{tabular}{llc}
\hline & Bekasi & $13 \%$ \\
& Bogor & $10 \%$ \\
Travel Companion & Others & $2 \%$ \\
& Free Individual Travelers & $29 \%$ \\
& Friends & $15 \%$ \\
& Family & $40 \%$ \\
Visiting Frequency & Group & $16 \%$ \\
& First time & $68 \%$ \\
& $2-5$ times & $30 \%$ \\
\hline
\end{tabular}

Table 3. shows the results of 145 questionnaires were distributed to tourists. They filled out a questionnaire containing indicators of satisfaction of budget hotel guests based on sensory experience.

Table 3. questionnaire influence of sensory experience on budget hotel guest satisfaction

\begin{tabular}{|c|c|c|c|}
\hline \multirow[t]{2}{*}{ Dimensions } & \multirow[t]{2}{*}{ Indicators } & \multicolumn{2}{|c|}{ Measurement } \\
\hline & & Mean & $\begin{array}{c}\text { Std. } \\
\text { Deviation }\end{array}$ \\
\hline \multirow[t]{2}{*}{ Tactile Experience } & $\begin{array}{l}\text { Smooth and comfort of the } \\
\text { linen }\end{array}$ & 4.25 & .884 \\
\hline & $\begin{array}{l}\text { The mattress is comfortable to } \\
\text { support quality sleep }\end{array}$ & 3.94 & .775 \\
\hline \multirow[t]{3}{*}{ Visual Experience } & $\begin{array}{l}\text { Room color theme influences } \\
\text { comfort when staying } \\
\text { overnight }\end{array}$ & 4.15 & .808 \\
\hline & $\begin{array}{l}\text { Room Design and layout is } \\
\text { outstanding }\end{array}$ & 4.20 & .851 \\
\hline & $\begin{array}{l}\text { Splendid view outside the } \\
\text { hotel }\end{array}$ & 3.95 & .804 \\
\hline \multirow[t]{2}{*}{ Olfactory Experience } & Room has clean fragrances & 4.09 & .845 \\
\hline & $\begin{array}{l}\text { No foul smell from the } \\
\text { bathroom }\end{array}$ & 4.19 & .778 \\
\hline \multirow[t]{2}{*}{ Gustative Experience } & $\begin{array}{l}\text { Room service meals or } \\
\text { breakfast are tasty }\end{array}$ & 3.78 & .977 \\
\hline & Hotel served local delicacies & 4.05 & .855 \\
\hline \multirow[t]{2}{*}{ Auditory Experience } & $\begin{array}{l}\text { Noise from outside the hotel } \\
\text { is isolated }\end{array}$ & 3.15 & .791 \\
\hline & $\begin{array}{l}\text { In room voice is unable to } \\
\text { hear from outside }\end{array}$ & 3.57 & .794 \\
\hline Staying Satisfaction & $\begin{array}{l}\text { Feeling satisfied and pleased } \\
\text { overall }\end{array}$ & 4.23 & .798 \\
\hline
\end{tabular}

Note: Sensory experience is measured by 5 point scale ranging from $1=$ Strongly Disagree, 2=Disagree, $3=$ Neutral, $4=$ Agree, $5=$ Strongly Agree

Data shows that sensory experience is a dominant part of guest satisfaction factors in staying at a budget hotel. In table 3, the majority of respondents agreed 
that the indicators mentioned influenced guest satisfaction during their stay. Among the points above, the most dominant is an indicator that says that smooth linen, room odor and room design affects the comfort of staying above 4.00 of the most data compared to other indicators. However, soundproof from exterior and interior room were considered to be improved.

As can be seen in figure 2, this study explains that the sensory experience felt by guests when in a budget hotel affects customer satisfaction. Moreover, the sensory that they feel makes comfortable by budget class hotels. Today's budget hotels still provide maximum service even with simple facilities, because the comfort of guests is an important part of every hotel. Therefore, budget hotels can optimize 3 dimensions of the sensory experience indicator to provide guests comfort.

Afterwards, whenever the modest service from budget hotel meets guests expectations, the sensory experience dimensions are typically adjustable according to hotel's policy. Therefore, to maximize guests comfort from their visits, hotel management needs to explore their service from particular dimensions.

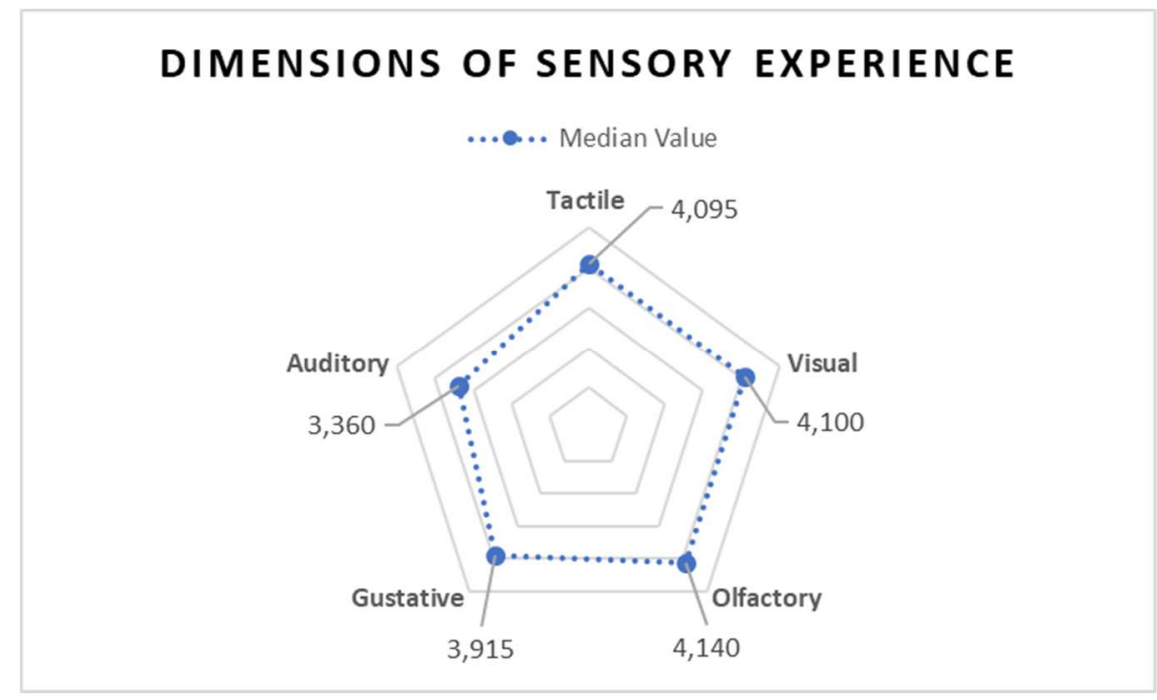

Fig.2 Result From Dimensions of Sensory Experience

\section{CONCLUSION}

In conclusion, dimensions of sensory experience in budget hotel are dominant in tactile, visual and olfactory. However, auditory and gustative activity are less sensed by the guests and eventually creates dissatisfaction. These dimensions are tend to be adjustable with management strategy to win the competition. Ultimately budget hotel management has two options, firstly improving the tactile, visual and olfactory services. Secondly, enhancing auditory and gustative service and upholding the rests sensory experience dimensions. If this trend continues in the near future, budget hotel will have big opportunity to compete with classified hotels. Thus, the number of positive review will increase significantly. 


\section{REFERENCES}

Agapito, D. (2020). The senses in tourism design: A bibliometric review. Annals of Tourism Research, 83(March). https://doi.org/10.1016/j.annals.2020.102934

Agapito, D., Valle, P., \& Mendes, J. (2012). Sensory Marketing and Tourist Experiences. Spatial and Organizational Dynamics Discussions Papers, 10, 7-19.

Aryani, Dwi, and F. R. (2011). Pengaruh kualitas layanan terhadap kepuasan pelanggan dalam membentuk loyalitas pelangga. Bisnis \& Birokrasi Journal, 2(172).

Bakhtiar, Arfan, Aries Susanty, and F. M. (2010). Analisis kualitas pelayanan yang berpengaruh terhadap kepuasan pelanggan menggunakan metode servqual dan model kano (studi kasus: PT. PLN UPJ Semarang Selatan). J@,Ti Undip: Jurnal Teknik Industri 5, 2, 77-84.

Bogdan \& Biklen, S. (1992). (2009). Penelitian Kualitatif. In Journal Equilibrium: Vol. 5 No. 9 (pp. 1-8).

Budhi Danudara, A. (2016). Pengembangan Experiental Marketing di Saung Angklung Udjo Bandung.

Dai, T., \& Zheng, X. (2021). Understanding how multi-sensory spatial experience influences atmosphere, affective city image and behavioural intention. Environmental Impact Assessment Review, 89(March), 106595. https://doi.org/10.1016/j.eiar.2021.106595

GUZEL, O., \& DORTYOL, T. (2016). Exploring the Multi-Sensory Based Memorable Tourism Experiences: A Study of Adam\&Eve Hotel in Turkey. Journal of Marketing and Consumer Behaviour in Emerging Markets, 2(4), 28-39. https://doi.org/10.7172/2449-6634.jmcbem.2016.2.2

Hudspeth, A., \& Logothetis, N. K. (2000). Sensory systems. In Current Opinion in Neurobiology (Vol. 10, Issue 5, pp. 631-641). https://doi.org/10.1016/S0959-4388(00)00133-1

Kastenholz, E., Marques, C. P., \& Carneiro, M. J. (2020). Place attachment through sensory-rich, emotion-generating place experiences in rural tourism. Journal of Destination Marketing and Management, 17(August). https://doi.org/10.1016/j.jdmm.2020.100455

Kim, D., \& Perdue, R. R. (2013). The effects of cognitive, affective, and sensory attributes on hotel choice. International Journal of Hospitality Management, 35, 246-257. https://doi.org/10.1016/j.ijhm.2013.05.012

Kotler, P. (2000). Marketing Management, Millenium Edition. Marketing Management, 23(6), 188-193. https://doi.org/10.1016/0024$\underline{6301(90) 90145-\mathrm{T}}$

Mehraliyev, F., Kirilenko, A. P., \& Choi, Y. (2020). From measurement scale to sentiment scale: Examining the effect of sensory experiences on online review rating behavior. Tourism Management, 79(February), 104096. https://doi.org/10.1016/j.tourman.2020.104096

Mohsin, A., \& Lengler, J. (2015). Service experience through the eyes of budget hotel guests: Do factors of importance influence performance dimensions? Journal of Hospitality and Tourism Management, 23, 23-34. 
https://doi.org/10.1016/j.jhtm.2015.03.001

Mylonas, D., \& MacDonald, L. (2017). Colour naming for colour design. In Colour Design: Theories and Applications: Second Edition (pp. 131-155). https://doi.org/10.1016/B978-0-08-101270-3.00005-9

Nurwulandari, R., \& Kurniawan, K. R. (2020). "Europa in de Tropen", The Colonial Tourism and Urban Culture in Bandung. Journal of Architectural Design and Urbanism, 2(2), 15-23. https://doi.org/10.14710/jadu.v2i2.7147

Rahman, N. H. A., Khalifah, Z., \& Ismail, H. N. (2015). Conceptual framework for experiences' quality based on senses' perception with behaviour as a mediator: In the context of cultural heritage attractions. Advanced Science Letters, 21(5), 1135-1140. https://doi.org/10.1166/asl.2015.6017

Rahman, N. H. A., Wirakusuma, R. M., \& Dasipah, E. (2021). Re-examining sensory experience on highland nature-based resort rooms. Promoting Creative Tourism: Current Issues in Tourism Research: Proceedings of the 4th International Seminar on Tourism (ISOT 2020), November 4-5, 2020, Bandung, Indonesia, 503-508. https://www.taylorfrancis.com/chapters/edit/10.1201/978100309548472/re-examining-sensory-experience-highland-nature-based-resortrooms-rahman-wirakusuma-dasipah

Sachari. (2007). Budaya Visual Indonesia: membaca makna perkembangan gaya visual karya desain di Indonesia abad ke-20. Erlangga.

Sthapit, E., \& Jiménez-Barreto, J. (2018). Exploring tourists'memorable hospitality experiences: An Airbnb perspective. Tourism Management Perspectives, 28(February), 83-92. https://doi.org/10.1016/j.tmp.2018.08.006

Sugiyono, 2006. Metode Penelitian Kuantitatif, Kualitatif, dan Penelitian \& Pengembangan. Bandung: Alfabeta

Wickens, C. D., Gordon, S. E., \& Liu, Y. (2004). Visual Sensory Systems. In An introduction to human factors engineering.

Wulandari, H. (2014). Eksplorasi Pengalaman Panca Indera untuk Perancangan Interior. Dimensi Interior, 12(2). https://doi.org/10.9744/interior.12.2.85$\underline{90}$

Xuejing, Z., \& Huamin, L. (2009). Budget Hotel Customer Satisfaction Analysis Based on SERVQUAL Model. STRATEGIC MANAGEMENT ENGINEERING: ENTERPRISE, ENVIRONMENT AND CRISIS, 64-68. 